\title{
PENGELOLAAN PEMBELAJARAN KONTEKSTUAL PENDIDIKAN AGAMA ISLAM
}

\author{
Akhmad Ilman Nafia \\ Dosen UNDARIS, Semarang \\ e-mail: ahmadilman@yahoo.com
}

\begin{abstract}
The management of contextual learning in Islamic Education consist of planning which is done by technical and non technical analysis, and planning of the learning scenarios related to the material and the objective conditions that is experienced by the students. The implementation of contextual learning of Islamic education was the inquiry, questioning, learning community, modeling, reflecting, and contextual learning evaluation to the behavioral change, the school community as the basic of valuation.
\end{abstract}

\section{Keywords: Management, Contextual Learning, Islamic Education}

\section{PENDAHULUAN}

Pendidikan sebagai bagian penting dalam kehidupan masyarakat di era global seharusnya mampu memfasilitasi perkembangan kecerdasan baik intelektual, emosional dan spiritual. Gulen sebagaimana dikutip Asfaruddin (2005: 18-19) menyatakan bahwa hakikat pendidikan adalah tempat pelatihan dari semua aspek kondisi manusia dalam mempromosikan pengembangan holistik individu, spiritual, moral, rasional dan psikologis. Kualitas pendidikan tidak hanya terdeskripsikan dibalik simbol angka saja, namun pendidikan juga harus mampu menghasilkan Sumber Daya Manusia (SDM) yang berkualitas. Seperti yang diungkapkan oleh Suprijono (2011: vi) bahwa keterampilan intelektual, sosial, dan personal dibangun tidak hanya dengan landasan rasio dan logika saja, tetapi juga inspirasi, kreativitas, moral, intuisi dan spiritual.

Tujuan pendidikan nasional dalam Undang-undang Nomor 20 Tahun 2003 tentang Sistem Pendidikan Nasional menyatakan bahwa pendidikan nasional berfungsi untuk mengembangkan kemampuan dan membentuk watak serta peradaban bangsa yang bermartabat dalam rangka mencerdaskan kehidupan bangsa, dan bertujuan untuk mengembangkan potensi peserta didik agar menjadi manusia yang beriman dan bertakwa kepada Tuhan Yang Maha Esa, berakhlak mulia, sehat, berilmu, cakap, kreatif, mandiri dan menjadi warga negara yang demokratis serta bertanggungjawab.

Salah satu ciri manusia berkualitas dalam rumusan UU No. 20 Tahun 2003 di atas adalah mereka yang tangguh iman dan takwanya serta memiliki akhlak mulia, 
artinya salah satu indikator kompetensi dalam pendidikan nasional adalah keunggulan dalam iman dan takwa serta memiliki akhlak yang mulia. Hakikat tujuan pendidikan nasional menjelaskan bahwa sistem pendidikan nasional menempatkan peserta didik sebagai makhluk yang diciptakan oleh Tuhan dengan segala fitrahnya dengan tugas memimpin pembangunan kehidupan yang berharkat dan bermartabat, sebagai makhluk yang mampu menjadi manusia yang bermoral, berbudi luhur, dan berakhlak mulia. Oleh karena itu, pendidikan merupakan upaya memberdayakan peserta didik untuk berkembang menjadi manusia seutuhnya, yaitu yang menjunjung tinggi dan memegang dengan teguh norma-norma agama dalam kehidupan sehari-hari, baik sebagai makhluk Tuhan Yang Maha Esa, makhluk individu, maupun makhluk sosial.

Rosnani Hasyim dalam jurnal internasional berpendapat bahwa people fulfill their roles as 'abd and khalifah, all of their intellectual, physical, spiritual, emotional, moral, social, and other potentials have to be developed. Therefore, the role of education and instruction is to initiate the germination and later flowering of each child's potential. To this effect, Islamic education is designed to produce God-conscious (taqwa) people who serve
Him and who are aware of their individual vertical relations with Him (hablu min Allah) and their horizontal social relations with their fellow human beings (hablu min alnas). Kemudian di dalam surat At Tahrim (66) ayat 6 Allah berfirman "hai orang-orang yang beriman, peliharalah dirimu dan keluargamu dari api neraka yang bahan bakarnya adalah manusia dan batu; penjaganya malaikat-malaikat yang kasar, keras, dan tidak mendurhakai Allah terhadap apa yang diperintahkan-Nya kepada mereka dan selalu mengerjakan apa yang diperintahkan".

Pendidikan Islam sebagai bagian integral dari pendidikan nasional memiliki peran yang strategis dalam merealisasikan tujuan besar pendidikan nasional khususnya pembentukan dalam aspek iman dan taqwa. Seperti yang diungkapkan oleh Mahmud AlSayyid (Suharto, 2011: 168) pendidikan Islam harus mencakup aspek kognitif (fikkriyah ma'rafiyah), affektif (khuliqiyyah), psikomotorik (jihadiyyah), spiritual (ruhiyyah) dan sosial kemasyarakatan (ijtima'iyah). Dalam pandangan Islam, kompetensi iman dan takwa (imtak) serta ilmu pengetahuan dan teknologi (iptek), juga akhlak mulia diperlukan oleh manusia dalam melaksanakan tugasnya sebagai khalifah di muka bumi. Jadi, dapat di garis bawahi 
bahwa dalam pandangan Islam, peran kekhalifahan manusia dapat direalisasikan melalui dua hal, yaitu; pertama Landasan yang kuat berupa iman dan takwa, kedua Penguasaan ilmu pengetahuan dan teknologi.

Tantangan yang dihadapi dalam Pendidikan Islam saat ini adalah mulai tergerusnya budaya Islam ke dalam arus globalisasi. Pendidikan agama yang disampaikan di kelas seakan hanyalah pertemuan formal yang hanya mengena dalam aspek kognitif saja, seharusnya pendidikan Islam tidak hanya mengajarkan pengetahuan tentang agama saja akan tetapi jauh lebih penting bagaimana membentuk kepribadian siswa agar memiliki keimanan dan ketakwaan yang kuat dan kehidupannya yang senantiasa dihiasi dengan akhlak yang mulia di manapun mereka berada, dan dalam posisi apapun mereka bekerja. Maka saat ini yang mendesak adalah bagaimana usahausaha yang harus dilakukan oleh para guru Pendidikan Agama Islam untuk mengembangkan metode-metode pembelajaran yang dapat memperluas pemahaman peserta didik mengenai ajaranajaran agamanya, mendorong mereka untuk mengamalkannya dan sekaligus dapat membentuk akhlak dan kepribadiannya.

Salah satu metode pembelajaran yang dapat diterapkan dalam pembelajaran Pendidikan Agama Islam adalah dengan
Pendekatan Kontekstual. Seperti yang diungkapkan Jauhar (2011: 182) berikut Pembelajaran Kontekstual adalah konsep belajar yang membantu guru mengaitkan antara materi pembelajaran dengan situasi dunia nyata siswa, dan mendorong siswa untuk membentuk hubungan antara pengetahuan yang dimilikinya dengan penerapannya dalam kehidupan mereka sehari-hari

\section{METODE PENELITIAN}

Penelitian ini adalah penelitian kualitatif dengan pendekatan library research. Metode pengumpulan data yang digunakan dalam penelitian ini adalah observasi berita, dan studi dokumen literaturliteratur tentang pembelajaran kontekstual. Observasi merupakan salah satu teknik pengumpulan data yang digunakan dalam penelitian kualitatif (Emzir, 2011). Sebagai metode ilmiah, observasi biasanya diartikan sebagai pengamatan dan pencatatan dengan sistematis atas fenomena-fenomena yang diteliti. Kemudian teknik dokumentasi yang digunakan adalah mencari data mengenai hal-hal yang berupa catatan, transkip, buku, surat kabar, majalah, prasasti, notulen rapat, legger, dan agenda. Aktivitas dalam analisis data penelitian ini dilakukan secara interaktif dan berlangsung secara terus menerus pada setiap tahapan penelitian sehingga sampai tuntas, dan datanya sampai jenuh 


\section{HASIL PENELITIAN DAN PEMBAHASAN}

Metode berasal dari istilah yunani meta yang berarti melalui dan hodos berarti jalan yang dilalui, dalam bahasa arab, metode diungkapkan dalam istilah thariqah atau uslub (Suharto, 2011:134). Sedangkan menurut Djamarah (2000: 19) metode adalah suatu cara yang dipergunakan untuk mencapai tujuan yang telah ditetapkan.

Pembelajaran kontekstual merupakan prosedur pendidikan yang bertujuan membantu peserta didik memahami makna bahan pelajaran yang mereka pelajari dengan cara menghubungkanya dengan konteks kehidupan mereka sendiri dalam lingkungan sosial dan budaya masyarakat (Suprijono, 2011: 80). Menurut Trianto (2011: 102) pembelajaran kontekstual adalah pengajaran yang memungkinkan siswa TK sampai dengan SMU untuk menguatkan, memperluas, dan menerapkan pengetahuan dan ketrampilan akademik mereka dengan berbagai macam tatanan dalam sekolah dan luar sekolah agar dapat memecahkan masalah masalah dunia nyata dan masalah masalah yang disimulasikan.

Johson (2011: 60) menjelaskan bahwa pembelajaran kontekstual adalah sebuah sIstem yang menyeluruh. Pembelajaran kontekstual terdiri dari bagian-bagian yang saling terhubung. Jika bagian-bagian ini terjalin satu sama lain, maka akan dihasilkan pengaruh yang melebihi hasil yang diberikan bagian bagianya secara terpisah. Seperti halnya biola, cello, clarinet, dan alat music lain di dalam sebuah orchestra yang menghasilkan bunyi yang berbeda beda yang secara bersama sama menghasilkan music, demikian juga bagian bagian pembelajaran kotekstual yang terpisah melibatkan prosesproses yang berbeda, yang ketikan digunakan secara bersama sama, memampukan para siswa membuat hubungan yang menghasilkan makna. Setiap bagian pembelajaran kontekstual yang berbeda beda ini memberikan sumbangan dalam menolong siswa memahami tugas sekolah. Secara bersama sama, mereka membentuk suatu system yang memungkinkan para siswa melihat makna di dalamnya, dan mengingat materi akademik. Dari pernyataan para ahli tersebut dapat disimpulkan bahwa pembelajaran kontekstual merupakan metode atau jalan bagi pengajar untuk mentransformasikan pengetahuan dengan memahami makna bahan pelajaran yang mereka pelajari dengan cara menghubungkanya dengan konteks kehidupan mereka sendiri dalam lingkungan sosial dan budaya masyarakat.

Sagala (2009: 88) menyebutkan bahwa konstruktivisme (constructivism) merupakan landasan berpikir (filosofi) 
pembelajaran kontekstual. Menurut Suprijono (2011: 30) gagasan kontruktivism mengenai pengetahuan dapat dirangkum sebagai berikut 1) pengetahuan bukanlah gambaran dunia nyata, tetapi selalu merupakan kontruksi melalui kegiatan subjek; 2) subjek membentuk skema kognitif, kategori, konsep dan struktur yang perlu untuk pengetahuan; dan 3) pengetahuan dibentuk dalam struktur konsep seseorang. Struktur konsep membentuk pengetahuan jika konsep itu berlaku dalam berhadapan dengan pengalaman pengalaman seseorang. Fondasi utama pembelajaran aktif, inovatif, kreatif, effektif dan menyenangkan adalah kontruktivisme, maka dari itu beberapa model pembelajaran dikembangkan seperti pembelajaran langsung, pembelajaran kooperatif, dan pembelajaran berbasis masalah, pada dasarnya model pembelajaran ini berorientasi pada pengetahuan yang mampu mengatasi segala permasalahan kehidupan manusia didik.

Suatu hal yang penting adalah teori kontruktivisme adalah situated cognition (kognisi yang ditempatkan), konsep ini selalu menempatkan pengetahuan pada posisi cultural dan secara mendalam ditempatkan pada konteks sosial dan fisik, bukan hanya berhenti pada batasan pikir manusia. Pengetahuan selalu ditempatkan pada konteks di mana pengetahuan tersebut dapat diaplikasikan. Cobern (Suprijono, 2011: 79) mengungkapkan bahwa kontruktivisme bersifat kontekstual. Maka dari itu pembelajaran harus diciptakan semirip mungkin dengan situasi "dunia nyata" pembelajaran yang dimaksud adalah pembelajaran kontekstual.

\section{Menurut Johnson (2009:}

pembelajaran kontekstual adalah sebuah proses pendidikan yang bertujuan menolong para siswa melihat makna di dalam materi akademik yang mereka pelajari dengan cara menghubungkan subjek-subjek akademik dengan konteks dalam kehidupan keseharian mereka, yaitu dengan konteks keadaan pribadi, sosial, dan budaya mereka. Untuk mencapai tujuan ini, sistem membuat keterkaitan-keterkaitan yang bermakna, melakukan pekerjaan yang berarti, melakukan pembelajaran yang diatur sendiri, melakukan kerja sama, berpikir kreatif dan kritis, mencapai standar yang tinggi, dan menggunakan penilaian autentik. Adapun Suprijono (2011: 80) mengemukakan bahwa pembelajaran kontekstual juga dikenal dengan experiential learning, real world education, active learning, dan learned centered instruction. Trianto (2011: 104) menjelaskan pembelajaran kontekstual dapat dikatakan sebagai sebuah pendekatan pembelajaran yang mengakui dan menunjukan kondisi alamiah dari 
pengetahuan. Melalui pendekatan di dalam dan di luar kelas, suatu pendekatan pembelajaran kontekstual menjadikan pengalaman lebih relevan dan berarti bagi siswa dalam membangun pengetahuan yang akan mereka terapkan dalam pembelajaran seumur hidup.

Depdiknas (Trianto, 2011: 106) mengemukakan bahwa dalam pembelajaran kontekstual ada tujuh prinsip pembelajaran yang harus dikembangkan guru, yaitu: konstruktivisme (constructivism), menemukan (inquiry), bertanya (questioning), masyarakat belajar (learning community), pemodelan (modeling), refleksi (reflection), dan penilaian yang sebenarnya (authentic assessment). CTL dapat diterapkan dalam kurikulum apa saja, bidang studi apa saja, dan kelas yang bagaiamanapun keadaaanya.

\section{Pelaksanaan Pembelajaran Kontekstual Pendidikan Agama Islam}

a. Inkuiri (Inquiry)

Serulah (manusia) kepada jalan Tuhan-mu dengan hikmah dan pelajaran yang baik dan bantahlah mereka dengan cara yang baik. Sesungguhnya Tuhanmu dialah yang lebih mengetahui tentang siapa yang tersesat dari jalan-Nya dan dialah yang lebih mengetahui orang-orang yang mendapat petunjuk (QS. An-Nahl: 125).

Inquiry (Penemuan) merupakan bagian dari pembelajaran kontekstual, siswa atau peserta didik didorong untuk menemukan sendiri pengetahuan atau hikmah dalam pembelajaran, dalam pembelajaran kontekstual siswa di hadapkan pada sebuah kasus untuk didiskusikan dan dipecahkan. Hal ini secara langsung akan membentuk karakter dan mental peserta didik dalam mempertahankan argument yang dianggap benar dan akan membantah dengan dasar Al Qur'an dan Hadits jika ada sesuatu yang salah. Di dalam Al-Qur'an kata diskusi sama dengan Al-Mujadallah itu diulang sebanyak 29 kali, di antaranya adalah pada surat An-Nahl ayat 125. Dari ayat di atas Allah telah memberikan pengajaran bagi umat Islam agar membantah atau berargumen dengan cara yang baik. Dan tidak lain itu bisa kita temui dalam rangkaian acara yang biasa disebut diskusi. Diskusi juga merupakan metode yang langsung melibatkan anak didik untuk aktif dan kreatif dalam pembelajaran. Merupakan bagian inti dari kegiatan pembelajaran berbasis kontekstual. Pengetahuan dan ketrampilan yang diperoleh siswa diharapkan bukan 
hasil mengingat seperangkat fakta-fakta, tetapi hasil dari menemukan sendiri.

Guru harus selalu merancang kegiatan yang merujuk pada kegiatan menemukan, apa pun materi yang diajarkanya, siklus inquiry menurut Trianto (2011:108); Observasi, Bertanya, Mengajukan dugaan, Pengumpulan data, dan penyimpulan. Langkah langkah kegiatan inquiry adalah sebagai berikut; merumuskan masalah, mengamati atau melakukan observasi, menganilisis dan menyajikan hasil dalam tulisan, gambar, laporan, bagan table, karya lainya, dan mengkomunikasikan atau menyajikan hasil karya pada pembaca, teman sekelas, guru atau audien yang lain. Deal (2006), dalam penelitiannya "Voice From The Classroom: Literacy Belienfs and Practices of Two Novice Elementary Teachers" menyatakan bahwa pembelajaran secara bertahap memungkinkan siswa dapat memahami apa yang diajarkan oleh guru.

Menurut Suprijono (2011: 86) kata kunci dari pembelajaran kontekstual adalah “penemuan'. Belajar penemuan menunjuk pada proses hasil belajar. Belajar penemuan melibatkan peserta didik dalam keseluruhan proses metode keilmuan sebagai langkah sistemik menemukan pengetahuan yang baru atau membenarkan pengetahuan lama. Belajar penemuan mengintegrasikan aktifitas belajar peserta didik ke dalam metode penelitian sebagai landasan operasional melakukan investasi. Dalam investigasi peserta didik tidak hanya belajar memperoleh informasi namun peserta didik juga dituntut untuk mampu mengolah informasi tersebut ke dalam sebuah pengetahuan yang mampu diaplikasikan. Guru memberikan stimulus atau menggugah siswa untuk melakukan usaha berfikir atau usaha untuk menemukan sendiri hikmah dari setiap pembelajaran PAI, sehingga siswa menemukan sendiri pengetahuan tersebut, dan hal tersebut secara tidak langsung akan membangun kesadaran siswa, dibanding dengan pengetahuan yang diberikan guru (doktrin) kepada siswa.

Gambaran

pembelajaran

kontekstual, misalnya pembelajaran ibadah sholat, siswa diberikan gambaran terlebih dahulu mengenai manfaat gerakan sholat, misal dalam hal kesehatan gerakan sholat yang baik dan benar mampu mengembalikan tulang tulang yang tidak di tempatnya, setelah itu anak mempraktikan gerakan sholat yang baik dan benar dan selanjutnya melakukan musyawarah bersama, dengan pertanyaan "Siapa saja yang setelah sholat "baik dan 
benar "merasakan tubuhnya terasa segar, tidak ngantuk, dan tidak malas" selanjutnya siswa yang merasakan tubuhnya lebih segar memberikan pernyataanya, nah pertanyaan ini yang mampu membangkitkan pengetahuan atau menyakinkan siswa yang lain untuk membenarkan kebenaran bahwa sholat memang memiliki manfaat bagi kesehatan tubuh, sehingga siswa yang sudah percaya dan yakin terhadap hal tersebut selanjutnya akan melaksanakan sholat dengan gerakan yang baik dan benar, seperti contoh lain manfaat sholat untuk menenangkan hati yang bermasalah, sebelumnya diberikan gambaran ketika sholat dilakukan secara khusyuk maka akan bermanfaat pada ketenangan hati, hati yang tenang tidak akan cepat marah dan melakukan perbuatan jahat, sama seperti sebelumnya siswa diberikan pancingan pertanyaan terlebih dahulu, "apakah yang sholatnya khusyuk, hatinya menjadi tenang dan nyaman" siswa yang merasakan hatinya nyaman diberikan waktu untuk memberikan pernyataan di hadapan teman-temanya, sehingga siswa yang lain akan merasa bahwa sholat khusyuk dapat menjadikan hati tenang, sehingga selanjutnya siswa dalam sholat akan membangun pengetahuan sendiri untuk berusaha sholat dengan khusyuk.

\section{b. Bertanya (Questioning)}

Pembajaran

kontekstual

dilaksanakan dengan Tanya jawab interaktif dari keseluruhan unsur yang terlibat dalam pembelajaran, melalui tanya jawab diharapkan peserta didik mampu menggali informasi dan memiliki ketrampilan untuk melakukan konfirmasi, Suprijono (2011: 86) menjelaskan bahwa Kegiatan bertanya penting untuk menggali informasi, mengonfirmasikan apa yang sudah diketahui, dan mengarahkan perhatian pada aspek yang belum diketahuinya.

Salah satu cara untuk memperoleh pengetahuan adalah bertanya, bertanya merupakan salah satu strategi dalam pembelajaran kontekstual dalam menggali informasi, Trianto (2011: 110) mengungkapkan bahwa bertanya merupakan strategi utama yang berbasis kontekstual. Bertanya dalam pembelajaran dipandang sebagai kegiatan guru untuk mendorong, membimbing, dan menilai kemampuan berpikir siswa. Bagi siswa, kegiatan bertanya merupakan bagian penting dalam melaksanakan pembelajaran yang berbasis inquiry, yaitu menggali informasi, mengkonfirmasikan apa yang sudah diketahui, dan mengarahkan perhatian pada aspek yang belum diketahuinya. 
Dari pernyataan di atas, secara jelas digambarkan bahwa informasi yang didapat oleh peserta didik dalam memahami materi pembelajaran, didapat dari hasil bertanya, guru memberikan kesempatan seluasnya kepada siswa untuk menggali informasi dengan bertanya kepada siapapun seluruh warga sekolah termasuk pegawai TU, tukang kebun, teman sejaawat, atau jika diperlukan guru mendatangkan narasumber untuk kepentingan pembelajaran. Bertanya merupakan aktifitas mandiri peserta didik yang merasakan sesuatu yang belum dipahami atau dimengerti, bertanya merupakan salah satu indikator motivasi belajar siswa dalam mengambil makna dari sebuah materi pembelajaran, dengan bertanya siswa dapat mendapatkan informasi yang dibutuhkan, dan guru dapat melakukan analisa terhadap pertanyaan siswa untuk menilai keberhasilan pembelajaran.

c. Maysarakat Belajar (Learning Community)

Konsep Learning Community menyarankan agar hasil pembelajaran diperoleh dari kerjasama dengan orang lain. Ketika seorang anak baru belajar tentang pembagian zakat misalnya, ia bertanya kepada temanya. Kemudian temanya yang sudah bisa menunjukan cara membagikan zakat yang benar menurut syariah, Maka dua orang anak tersebut sudah membentuk masyarakat belajar. Menurut Trianto (2011: 111) Hasil belajar yang diperoleh dari sharing antar teman, antar kelompok, dan antar yang tahu ke yang belum tahu. Di ruang ini, di kelas ini, di sekitar sini, juga orang orang yang ada di luar sana, semua adalah anggota masyarakat belajar.

Pembelajaran kontekstual menekankan arti penting pembelajaran sebagai proses sosial, melalui interaksi dalam komunitas belajar proses dan hasil belajar menjadi lebih bermakna. Hasil belajar diperoleh dari kolaborasi dan berkooperasi. Dalam praktiknya menurut Suprijono (2011: 87) "masyarakat belajar" terwujud dalam pembentukan kelompok kecil, pembentukan kelompok besar, mendatangkan ahli ke kelas, bekerja sama dengan pararel, bekerja kelas dengan kelas di atasnya, bekerja sama dengan masyarakat. Pernyataan ahli sesuai dengan hasil wawancara kepada guru dan siswa, learning community merupakan salah satu keutamaan dari pembelajaran kontekstual, karena pembelajaran harus bersifat komperhensif dimulai dari pendidik, teman peserta didik, pegawai, lingkungan 
belajar, seluruhnya harus mengacu pada tujuan pembelajaran.

Guru memberikan kesempatan belajar kepada teman sejawat yang memiliki kemampuan lebih, karena pada dasarnya pembelajaran adalah proses transformasi ilmu, transformasi ilmu tidak hanya dilakukan oleh guru kepada murid namun seluruh warga dan lingkungan sekolah harus bisa memberikan transformasi ilmu kepada peserta didik, karena pembelajaran kontekstual mengedepankan falsafah pembelajaran kontruktifisme di mana siswa menjadi pribadi yang mengembangkan, menemukan, menaganalisa, dan mengambil hikmah sendiri dari pembelajaran yang diikuti

Lingkungan menjadi sesuatu yang sangat membantu keberhasilan pembelajaran, prinsipnya anak lebih cepat memahami atau mempercayai jika temanya sendiri yang mengajarkan. Misalnya dalam membaca Al-Quran, bagi siswa yang masih kesulitan diberikan kesempatan untuk siswa yang sudah lancar atau fasih dalam membaca $\mathrm{Al}$ Quran untuk mengajari temanya yang masih kesulitan, metode seperti ini effektif mengingat guru tidak mungkin melakukan hal tersebut secara privat atau khusu, Selain itu kondusifitas lingkungan juga sangat mempengaruhi keberhasilan pembelajaran, misal dalam hal ibadah guru berupaya keras agar pelaksanaan pembelajaran berjalan kondusif, tenang dan nyaman untuk beribadah, dengan mempertimbangkan kebersihan tempat ibadah (masjid), tempat wudlu, dan agar pelaksanaan ibadah berjalan lancar khususnya dalam adzan dibuatkan jadwal adzan, agar tidak saling tunjuk.

\section{d. Permodelan (Modeling)}

Sesungguhnya telah ada pada (diri) Rasulullah itu suri teladan yang baik bagimu (yaitu) bagi orang yang mengharap (rahmat) Allah dan (kedatangan) hari kiamat dan dia banyak menyebut Allah (QS. Al-Ahzab: 21). Dalam Al-Qur'an kata teladan disamakan pada kata Uswah yang kemudian diberikan sifat dibelakangnya seperti sifat hasanah yang berarti baik. Sehingga dapat terungkapkan menjadi Uswatun Hasanah yang berarti teladan yang baik. Kata uswah dalam Al-Qur'an diulang sebanyak enam kali dengan mengambil contoh Rasullullah SAW, Nabi Ibrahim dan kaum yang beriman teguh kepada Allah. Dari firman Allah SWT dalam surat Al-Ahzab di atas Muhammad Quthb (1984: 183) mengisyaratkan bahwa di dalam diri Nabi Muhammad, Allah menyusun suatu 
bentuk sempurna metodologi Islam, suatu bentuk yang hidup dan abadi sepanjang sejarah masih berlangsung. Metode ini dianggap sangat penting karena aspek agama yang terpenting adalah akhlak yang termasuk dalam kawasan afektif yang terwujud dalam tingkah laku.

Pembelajaran

kontekstual menekankan $\operatorname{arti}$ penting pendemonstrasian terhadap hal yang dipelajari peserta didik. Pemodelan memusatkan pada arti penting pengetahuan prosedural. Melalui pemodelan peserta didik dapat meniru terhadap hal yang dimodelkan. Model bisa berupa cara mengoperasikan sesuatu, contoh karya tulis, melafalkan bahasa dan sebagainya (Suprijono, 2011: 88). Dalam sebuah pembelajaran ketrampilan atau pengetahuan tertentu, ada model yang bisa ditiru oleh siswanya, misalnya guru memodelkan langkah langkah gerakan sholat yang baik dan benar dengan demonstrasi sebelum siswanya melakukannya.

Dalam pembelajaran kontekstual, guru bukan satu satunya model. Pemodelan dapat dirancang dengan melibatkan siswa. Seorang bisa ditunjuk untuk memodelkan sesuatu berdasarkan pengalaman yang diketahuinya, Seluruh warga sekolah termasuk guru, pegawai, teman sejawat, lingkungan harus bisa menjadi model atau sesuatu yang bisa ditiru oleh siswa terutama dalam penampilan seperti busana muslim, budaya muslim seperti cium tangan guru, salam, tidak berbaur dengan non muhrim, berkata yang baik. Jika lingkungan sekolah bisa dijadikan model pembealajaran yang baik, maka peserta didik akan terbiasa dengan lingkungan atau budaya islami di sekolah, dan kebiasaan tersebut akan meresap kepada sikap peserta didik yang akan dilakukan di manapun tempatnya.

Dalam hal ini modelling dapat dilaksanakan misalnya guru, pegawai dan seluruh warga di sekolah bersama menjaga penampilan dan kepribadian, karena kepribadian merupakan salah satu kompetensi yang harus dipenuhi guru, sebagai contoh saja guru yang terkena kasus pemerkosaan yang ditampilkan ditelevisi atau media, hal tersebut sebenarnya berbahaya jika diketahui oleh siswa, karena siswa menganggap bahwa guru itu juga jahat, padahal ketika saya sekolah dulu guru itu benar benar seperti sosok yang sempurna, tidak pernah salah dan berbuat jahat, sehingga guru benar benar dikagumi, maka wajib bagi guru, pegawai untuk menggunakan pakaian muslim dan berperilaku sebagai seorang 
muslim, salah satu contoh kecil mengucap salam, mengajarkan siswa untuk cium tangan saat bersalaman dengan orang yang lebih tua, menjaga salam untuk yang berbeda jenis (bukan muhrim), selain itu lingkungan dan budaya sekolah juga harus dibuat Islami sehingga siswa itu akan terbiasa dan bangga terhadap budaya islami yang saat ini mulai luntur.

\section{e. Refleksi (Reflection)}

Keberhasilan pembelajaran tiada batas, karena pembelajaran kontekstual memprioritaskan perubahan perilaku yang sebaik baiknya, sehingga dibutuhkan refleksi untuk perbaikan pembelajaran selanjutnya. Mengubah perilaku anak untuk menjadi lebih baik merupakan sesuatu hal yang sangat sulit, karena anak tidak akan berubah jika guru hanya memberikan materi secara terus menerus seperti menyiram air, namun perubahan akan terjadi ketika anak atau siswa sadar dengan sendirinya tentang sesuatu yang dia anggap benar dilakukanya dan yang dia anggap salah dihindarinya, maka dalam hal ini guru mencoba untuk "menyalakan api" artinya kita harus menyalakan api atau memberikan rangsangan kepada siswa untuk menemukan kesadaran dalam pribadinya, seperti contoh dalam sholat dhuha, jika anak diberikan pengetahuan bahwa dengan sholat dhuha akan diberkahi rejekinya, rejeki yang berkah itu rejeki yang akan bermanfaat bagi kita ataupun diluar kita maka anak akan membuktikan kebenaran itu, dengan melurusnkan persepsi dari siswa tersebut, setiap hari kita diberikan oksigen gratis, rejeki orang tua kita yang diberikan untuk siswa, dan dibandingkan dengan pengalaman nyata orang yang kurang beruntung, sehingga siswa akan mengolah dengan sendirinya informasi tersebut dan harapanya akan masuk pada nurani dan merubah perilaku, karena perilaku yang salah didasari dengan pemikiran yang salah juga, jadi kita sebagai pengajar mencoba untuk memberikan informasi yang benar dan berdasar.

\section{Evaluasi Pembelajaran Kontekstual Pendidikan Agama Islam dalam Meningkatkan Ibadah Siswa}

Hasil dokumentasi yang peneliti peroleh terkait penilaian pembelajaran kontekstual Pendidikan Agama Islam Adalah Sebagai berikut.

a. Pembelajaran kontekstual Pendidikan Agama Islam dalam meningkatkan ibadah siswa adalah perubahan perilaku yang dialami siswa, khususnya kesadaran dalam menjalankan ibadah 
dan mengilhaminya dalam bentuk perilaku keseharian; dan

b. Instrumen

penilaian

dalam

pembelajaran kontekstual ada dua yaitu instrumen tes dan instrumen non tes.

1) Instrumen Tes

Prinsip penilaian dalam instrument test adalah objektivitas dan subjektif berdasar, dalam hal ini karakteristik penilaian instrument test ini adalah sebagai berikut.

a) Benar Salah (true and false);

b) Menjodohkan (Matching);

c) Pilihan Ganda (Multiple choice);

d) Test Uraian Bebas (Extended responses test); dan

e) Test Uraian Terbatas (Restriced Response Test).

2) Instrumen Non Tes

Instrumen non tes merupakan bagian dari alat ukur hasil belajar peserta didik. Instrument non test yang digunakan dalam pembelajaran kontekstual Pendidikan Agama Islam adalah; participation charts, checking lists, Rating scale, attitude scales.

\section{KESIMPULAN}

Perencanaan pembelajaran kontekstual Pendidikan Agama Islam 1) perencanaan diawali dengan analisa oleh guru terhadap kondisi lingkungan siswa; 2)
Identifikasi masalah yang di alami langsung oleh siswa; 3) mengaitkan permasalahan yang dialami oleh siswa ke dalam materi pembelajaran Pendidikan Agama Islam; 4) siswa dilibatkan dalam pembuatan konsep pembelajaran kontekstual. Pelaksanaan pembelajaran kontekstual Pendidikan Agama Islam menggunakan metode 1) menemukan (inquiry); 2) bertanya (questioning); 3) masyarakat belajar (learning community); 4) permodelan (modelling); dan 5) refleksi (reflection). Evaluasi pembelajaran kontekstual Pendidikan Agama Islam tidak hanya menggunakan penilaian angka, namun disertai dengan penilaian perilaku keseharian; perubahan perilaku menjadi prioritas penilaian dalam pembelajaran kontekstual Pendidikan Agama Islam; dan penilaian perilaku dilakukan secara menyeluruh (kesopanan, pergaulan, penampilan, kesadaran sosial, kesadaran menjalankan ibadah di sekolah dan di rumah).

\section{DAFTAR PUSTAKA}

Asfaruddin, Asma. (2005). The Philosophy of Islamic Education: Classical Views and M. Fethullah Gulen's Perspectives (fethullahgulenconference.org/housto n/read.php? $\mathrm{p}=$ philosophy-islamiceducation-classical-views-fethullahgulen-perspectives). 
Departemen Agama RI. (2003). Fiqh. Jakarta: Direktorat Kelembagaan Agama.

Djamarah, Syaeful Bahri. (2000). Guru dan Anak Didik dalam Interaksi Edukatif. Jakarta: PT Rineka Cipta

Emzir. (2011). Analisis Data: Metodologi Penelitian Kualitatif. Jakarta: Rajawali Press.

Jauhar, Muhammad. (2011). Implementasi Paikem Dari Behavioristik Sampai Kontruktivistik. Jakarta: Prestasi Pustaka Publiser

Johnson, Elaine B. (2011). Contextual Teaching and Learning Menjadikan Kegiatan Belajar-Mengajar Mengasikkan dan Bermakna. Bandung: Kaifa Learning

Rosnani, Hasyim. (2006). "Intellectualism in Higher Islamic Traditional Studies:
Implications for the Curriculume". The AJISS Vol. 24 (2006): 3.

Sagala, Syaiful. (2011). Konsep dan Makna Pembelajaran. Bandung: PT. Alfabeta

Sugiyono. (2010). Metode Penelitian Pendidikan Pendekatan Kuantitatif, Kualitatif, dan $R \& D$. Bandung: PT. Alfabeta.

Suharto, Toto. (2011). Filsafat Pendidikan Islam. Yogyakarta: Ar Ruzz Media

Suprijono, Agus. (2011). Cooperative Learning Teori dan Aplikasi PAIKEM, Yogyakarta: Pustaka pelajar

Trianto, (2007). Model-model pembelajaran inovatif berorientasi Konstruktivistik, Jakarta: Prestasi Pustaka Publisher. 